\title{
Recent developments in the isolation and synthesis of D-homosteroids and related compounds
}

\author{
János Wölfling \\ Department of Organic Chemistry, University of Szeged, Dóm tér 8, H-6720 Szeged, Hungary \\ E-mail:wolfling@chem.u-szeged.hu
}

This review is dedicated to Prof. Lutz F. Tietze on the occasion of his 65th birthday

\begin{abstract}
Both naturally occurring and synthetic D-homologs of compounds with a sterane skeleton exhibit diverse biological activity. The main sources of isolation are plants and marine organisms. The synthetic D-homosteroids are potential leads for drug discovery. This review focuses on steroids with a six-membered carbocyclic ring $\mathrm{D}$ and related compounds, the isolation or syntheses of which were reported between the mid-1990s and mid-2006.
\end{abstract}

Keywords: Steroids, D-homosteroids, isolation, partial synthesis, total synthesis

\section{Contents}

1. Introduction

2. D-homosteroids isolated from natural sources

3. Syntheses and transformations of D-homosteroids

3.1. Syntheses involving rearrangements

3.1.1. Cationic rearrangements

3.1.2. Anionic/radical rearrangements

3.2. Fragmentation - cyclization strategies

3.3. Total synthetic approaches

3.4. Miscellaneous transformations and investigations

4. Conclusions 


\section{Introduction}

Steroids are biomolecules that occur widely in nature and play key roles in the functioning of the human and animal organisms. Numerous members of this family of compounds, which can also be found in plants, exhibit varied biological activities. The series by Hanson in, "Natural Product Reports" regularly discuss the reactions and partial syntheses of diverse new steroids. ${ }^{1}$ Stéphan has reviewed the syntheses of modified steroids having a five-membered ring D in the androstane and androstene series. ${ }^{2}$ There is a steadily rising need to find effective drugs; one plausible way to satisfy this need is to combine two or more different molecules with different chemical and biological properties into one new, "hybrid". The features of these new entities often differ from those of the original compounds. Mehta et al. ${ }^{3}$ and Tietze et al. ${ }^{4}$ have reported numerous examples of the synthesis of natural products, including steroids, where this concept for the synthesis of new derivatives was utilized. Steroidal conjugates and their pharmacological applications have been discussed by Salunke et al. ${ }^{5}$ and the use of bile acids as building blocks of supramolecular hosts has been surveyed by Tamminen and Kolehmainen. ${ }^{6}$ Another possible way to obtain new, useful steroids for medicinal chemical purposes is to modify the original sterane skeleton, for example by the enlargement of ring $\mathrm{D}$. The insertion of one additional carbon atom in ring D may alter the biological properties. ${ }^{7}$ For example, the estrogen receptors recognize Dhomoestradiol (1) only poorly; the compound exhibit of three magnitude lower receptor binding affinity, then estradiol. ${ }^{8}$ On the other hand, D-homoestrone derivatives possess antioxidant properties. ${ }^{9}$ A number of attempts has been made to produce D-homosteroids. Some of the new compounds isolated exert anticancer effects. ${ }^{10,11}$ This review discusses the D-carbocyclic Dhomosteroids whose isolation, syntheses, structure determinations, biological activities and potential applications were reported between the mid-1990s and mid-2006. There are two different ways for obtaining D-homosteroids; the isolation from natural sources (Chapter 2) and the chemical synthesis and transformation of them (Chapter 3). Figure 1 shows the ring lettering, atom numbering, and the usual configurations of the stereogenic centers of the D-homosteroids on the examples of the D-homoestrane derivatives chosen $(\mathbf{1}, \mathbf{2})$. If not shown in the formulae, the positions of the hydrogen atoms at the stereogenic centers are $5 \alpha, 8 \beta, 9 \alpha, 14 \alpha$.
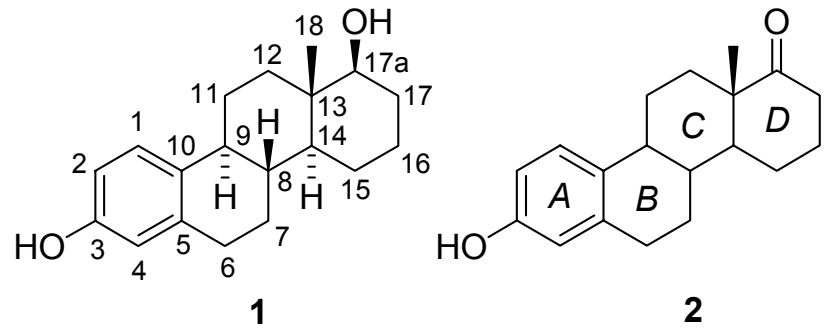

\section{Figure 1}




\section{D-Homosteroids isolated from natural sources}

Steroid alkaloids are usually found in higher plants and in animals. The toxic tomatidine, occurring as glycosides in Licopersicon esculentum and Solanum demissum inhibit the growth of human colon (HT29) and liver (HepG2) cancer cells. ${ }^{12}$ Batrachotoxin, produced by poison-arrow frogs, is one of the most toxic non-peptide compounds. ${ }^{13}$ All recently isolated natural derivatives discussed are C-nor,D-homosteroids. Two new steroidal alkaloids, veramine (3) and neojermininaline (4), together with the known glycoalkaloid pseudojervine, have been isolated from Veratrum album L. ${ }^{14}$ Veramine has been found to have a jervine-type skeleton, and neojermininaline a cevine-type skeleton (Fig. 2).

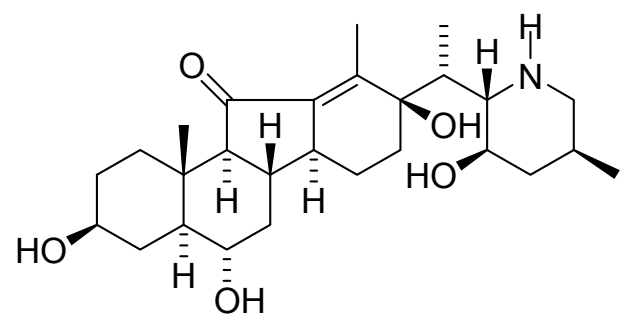

3

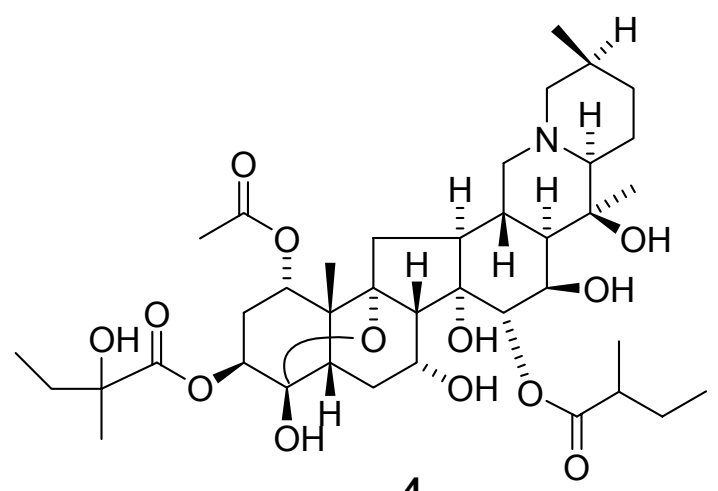

4

\section{Figure 2}

Germinine (5), isolated from Veratrum lobelianum Bernh, has a structure closely related to that of neojermininaline. ${ }^{15}$ Imperiazine (6) has been isolated from Petilium eduardi (Fig. 3). ${ }^{16}$

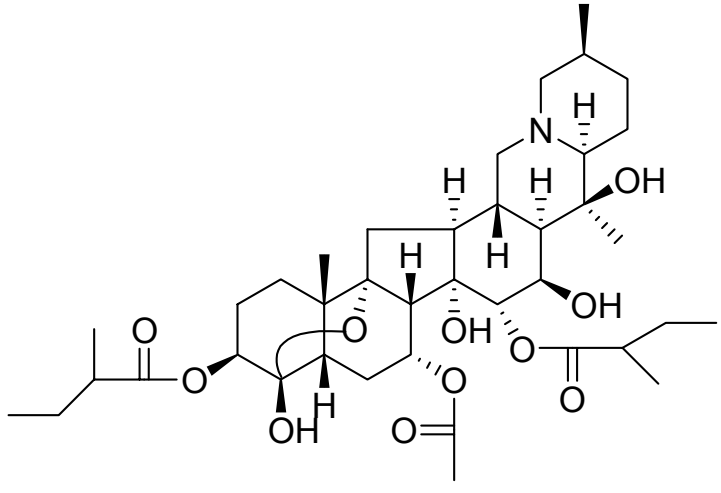

5

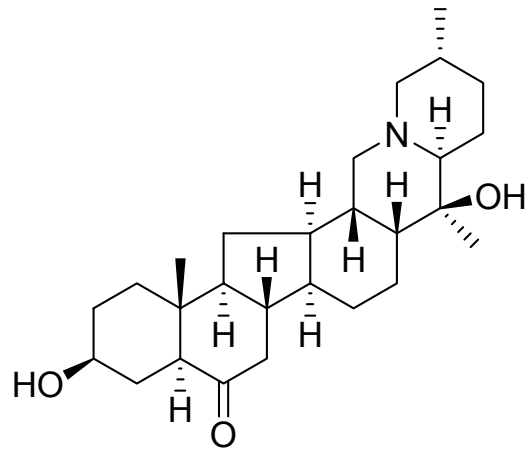

6

\section{Figure 3}

Two members of a new class of C-nor, D-homosteroid alkaloids, impranine (7) and dihydroimpranine (8), have been isolated from Fritillaria imperialis. ${ }^{17}$ Fritillaria puqiensis has 
furnished six new compounds, including five derivatives with the C-nor, D-homo structure: puqienines C-E (9-11), puqiedine (12) and 3 $\alpha$-puqiedin-7-ol (13; Fig. 4). ${ }^{18}$

Among twelve cardenolide glycosides obtained from Thevetia ahouai (LINN.), four proved to be new combinations of known aglycones and sugars, and nine were C-nor, Dhomocardenolide glycosides. ${ }^{19}$ One of the new compounds is thevetiogenin 3-O- $\beta$-gentobiosyl$(1 \rightarrow 4)$ - $\alpha$-L-rhamnopyranoside (14; Fig. 5). Atta-ur-Rahman and Choudhary have published a review on the chemistry of diterpenoid and steroid alkaloids published during 1996-1997. ${ }^{20}$

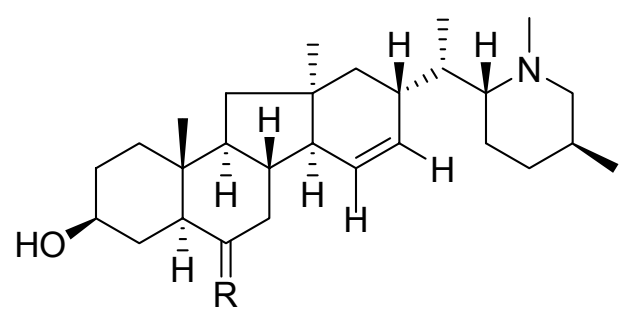

Impranine

$7 \mathrm{R}=\mathrm{O}$

Dihydroimpranine $8 \mathrm{R}=\mathrm{H}(\mathrm{OH})$

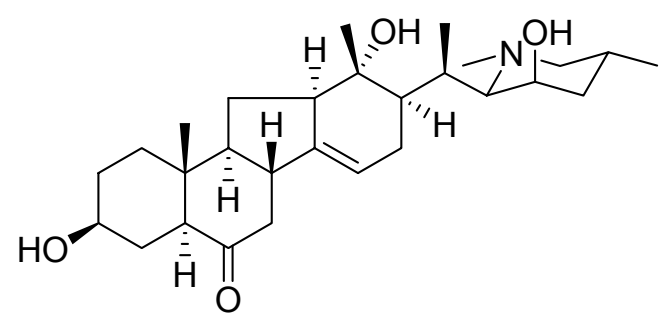

10

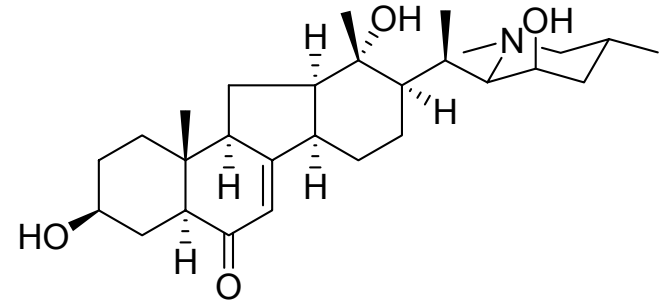

9

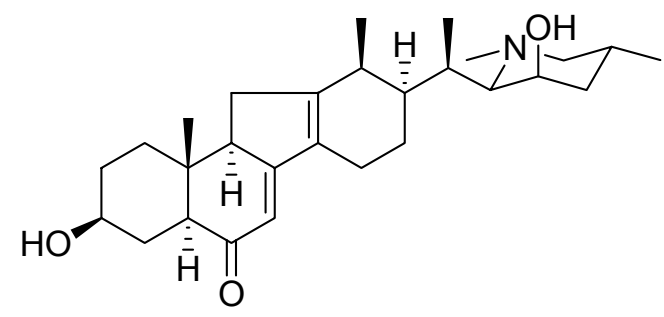

11

\section{Figure 4}




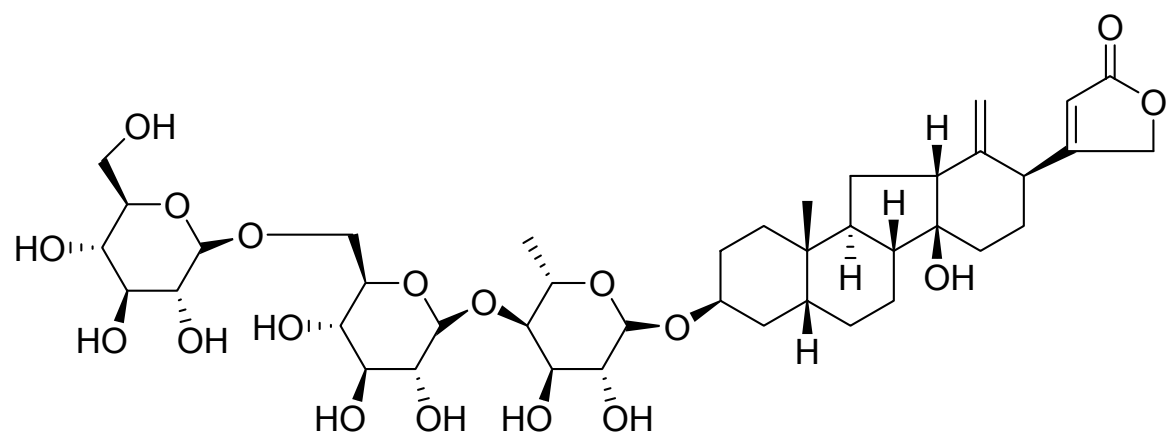

14

\section{Figure 5}

Biosynthetic products of marine organisms often contain halogens. Nakiterpiosin (15) and nakiterpinosinone (16) have been isolated from the Okinawan sponge Terpios hoshinota (Fig. 6). Both compounds, containing an aromatic ring $\mathrm{D}$, bromine and chlorine, exhibit potent cytotoxicity against mouse lymphocytic leukemia cells (P388). ${ }^{10,11}$

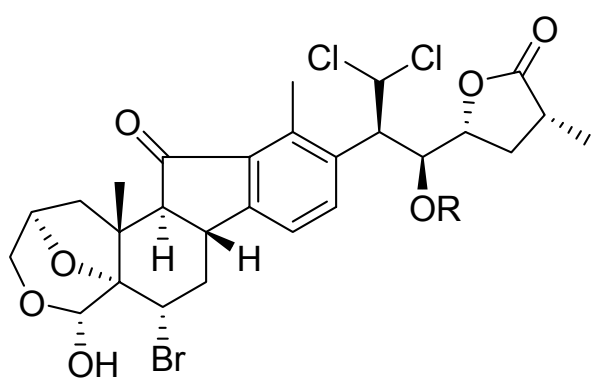

15

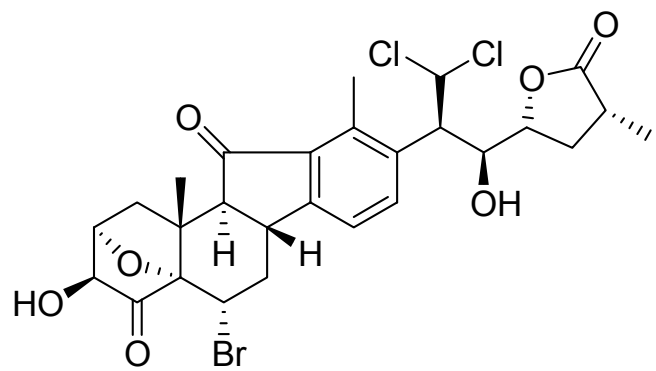

16

Figure 6

\section{Syntheses and transformations of D-homosteroids}

One plausible approach to the formation of D-homosteroids is the conversion of the fivemembered ring $\mathrm{D}$ of the naturally occurring steroids into a six-membered one. To achieve this goal, rearrangements or ring opening reactions, followed by cyclizations must be performed. An important advantage of this strategy is that the configurations of most chiral centers remain unchanged. However, the selectivities are often low or (in the case of ring-opening - ring-closure sequences) the synthetic routes involve numerous steps. 


\subsection{Syntheses involving rearrangements}

A classical route to the synthesis of D-homosteroids is the Tiffeneau rearrangement of 17aminomethyl-17-hydroxysteroids, which results in regioisomeric D-homosteroidal ketones. ${ }^{21}$ Successful attempts have been made meanwhile to increase the selectivity, ${ }^{22}$ and recently rearrangements have often been applied to obtain D-homopregnanes.

\subsubsection{Cationic rearrangements}

Lewis acid-catalyzed, one-step conversion of $16 \alpha, 17 \alpha$-epoxy-3 $\beta$-hydroxypregn-5-en-20-one (17) yielded chloro-substituted products: the D-homosteroid 18, exclusively or as the main product, with lesser amount of $\mathbf{1 9}$, depending on the reaction conditions (Scheme 1). ${ }^{23}$

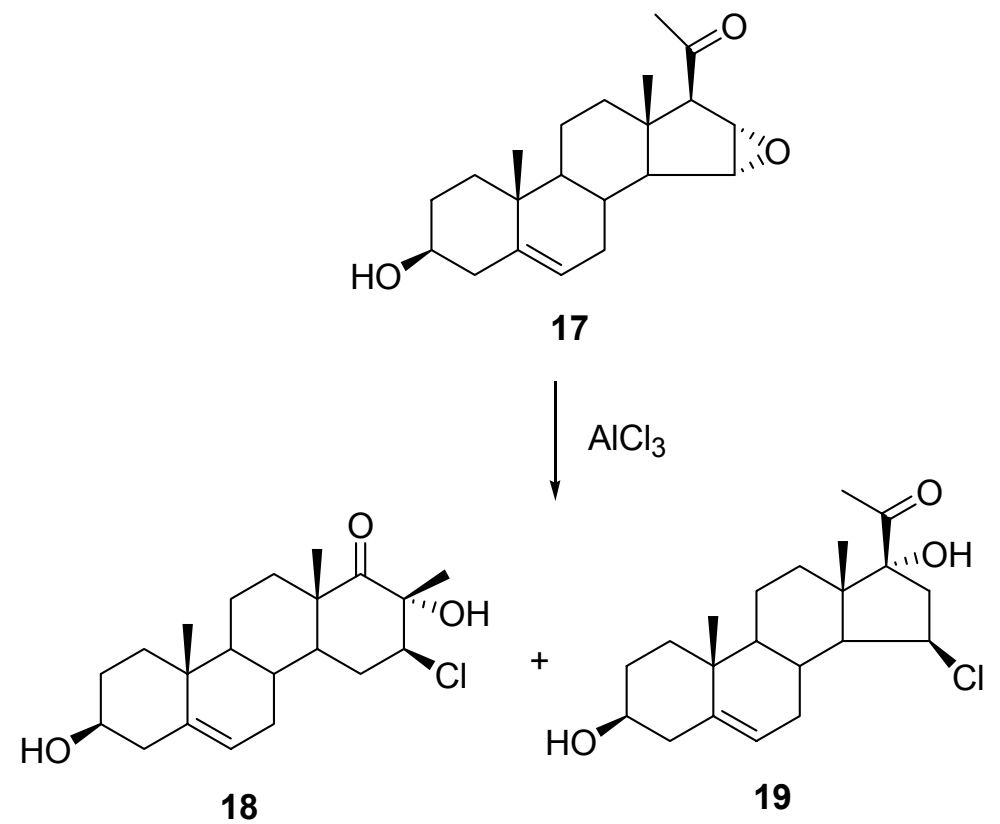

\section{Scheme 1}

Epoxide ring-opening of the protected pregnene derivative $\mathbf{2 0}$ with phenylmagnesium bromide led to the 16-phenyl-substituted alcohol 21, rearrangement of which with perchloric acid afforded the D-homosteroid 22 (Scheme 2). ${ }^{24}$ The synthesis and crystal structure determination of its oxidized derivative, 17 $\alpha$-acetoxy-17 $\beta$-methyl-16 $\beta$-phenyl-D-homo-4,6pregnadiene-3,17a-dione (23), have also been described. ${ }^{25}$ The inhibition of sodium acetate incorporation into lipids by this type of D-homosteroids has been investigated, ${ }^{26}$ as have their antiandrogenic effects. $^{27}$ 
<smiles>CC(=O)O[C@H]1CC[C@]2(C)CC[C@@H]3C(CC=C2C1)C1CCC3(C2(C)OCCO2)C1(C)C</smiles>

20<smiles>CC(=O)O[C@]1(C)C(=O)[C@]2(C)CC[C@H]3C(C=CC4=CC(=O)CC[C@]43C)C2C[C@H]1c1ccccc1</smiles>

23

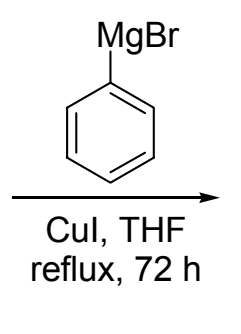

$\mathrm{HO}^{2}$<smiles>C[C@]12CC[C@H]3[C@@H](CC=C4C[C@@H](O)CC[C@]43C)[C@@H]1C[C@H](c1ccccc1)[C@@](C)(O)C2=O</smiles>

22

\section{Scheme 2}

The conversion of (20R)-20-iodopregn-4-en-3-one (24) into its iodosyl derivative by MCPBA resulted in a Wagner-Meerwein-type rearrangement with regioselective migration of the $\mathrm{C} 16-\mathrm{C} 17$ bond to give the D-homoandrostene 25 , with incorporation of C-20 into ring D, in good yield (Scheme 3$){ }^{28}$

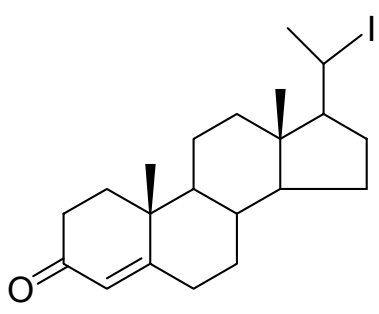

$24(20 R)$

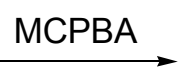<smiles>[R]O[C@]1(C)CC[C@H]2[C@@H]3CCC4=CC(=O)CC[C@]4(C)[C@H]3CC[C@H]2[C@H]1C</smiles>

$25\left(\mathrm{R}=\mathrm{H}, 3-\mathrm{ClC}_{6} \mathrm{H}_{4} \mathrm{CO}, \mathrm{Me}\right)$

\section{Scheme 3}

Two new C-nor, D-homocorticosteroids $(\mathbf{2 6}, \mathbf{2 7})$ were isolated from the filtrate of the triene carbonate during the production of betamethasone. Treatment of the $12 \beta$-hydroxycorticosteroid 25 with $\mathrm{PCl}_{5}$ resulted in the same products in a ratio of $1: 1$, which proves that a WagnerMeerwein rearrangement led to the formation of the C-nor, D-homocorticosteroids (Scheme 4). ${ }^{29}$ 
<smiles>C[C@]12C=CC(=O)C=C1CCC1C2C[C@H](O)[C@]2(C)C(C(=O)CO)CCC12</smiles>

25

$$
\begin{gathered}
\mathrm{PCl}_{5} / \mathrm{THF} \\
-78{ }^{\circ} \mathrm{C}
\end{gathered}
$$

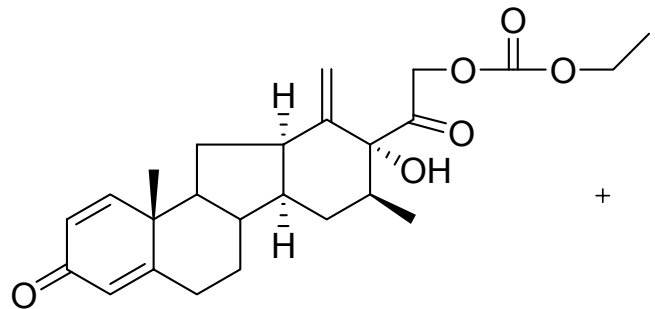

26

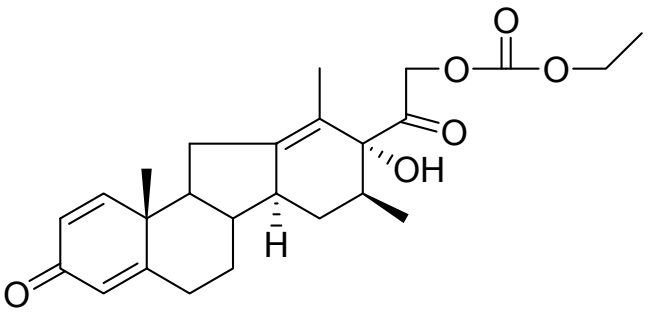

27

\section{Scheme 4}

Steroid diols of type $\mathbf{2 8}$ gave rearranged products (29) under acidic conditions (Scheme 5). ${ }^{30}$<smiles>C[C@]12CCC3CCC(CC31)C2(O)CC(=O)P</smiles>

28 $\stackrel{\text { acid }}{\longrightarrow}$<smiles>[R]c1cc2c(o1)[C@]1(C)CCC(C)C(C)C1CC2</smiles>

29

\section{Scheme 5}

\subsubsection{Anionic/radical rearrangements}

Steroidal 11,20-diketones 30, bearing a condensed cyclopropane ring on C-13 and C-17, rearranged under alkaline conditions to give D-homoandrostanes 31 (Scheme 6). ${ }^{31}$ 


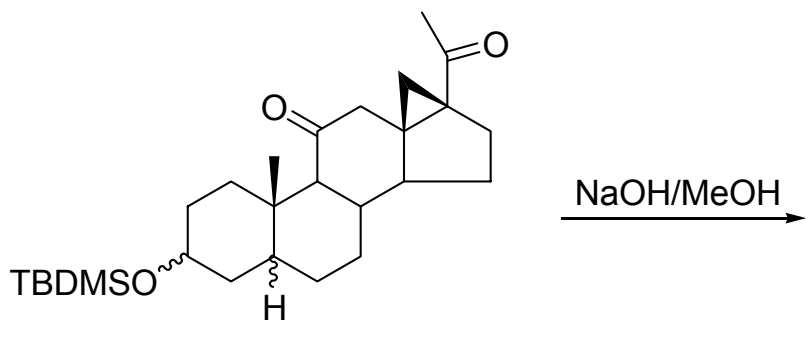

30<smiles>CC(=O)[C@H]1CCC2C(=CC(=O)C3C2CC[C@@H]2C[C@H](O)CC[C@]32C)C1</smiles>

31

\section{Scheme 6}

Rearrangements of 16,17-cyclopropane-fused androstenes have been described. Treatment of the hydrazone of $16 \alpha, 17 \alpha$-methylenepregnenolone acetate $(33)$ with $\mathrm{HgO} / \mathrm{Hg}(\mathrm{OAc})_{2}$, followed by the addition of $\mathrm{NaBH}_{4}$, led to the D-homosteroidal hydroxyketone $\mathbf{3 4}$ in a free-radical process (Scheme 7). ${ }^{31,32}$

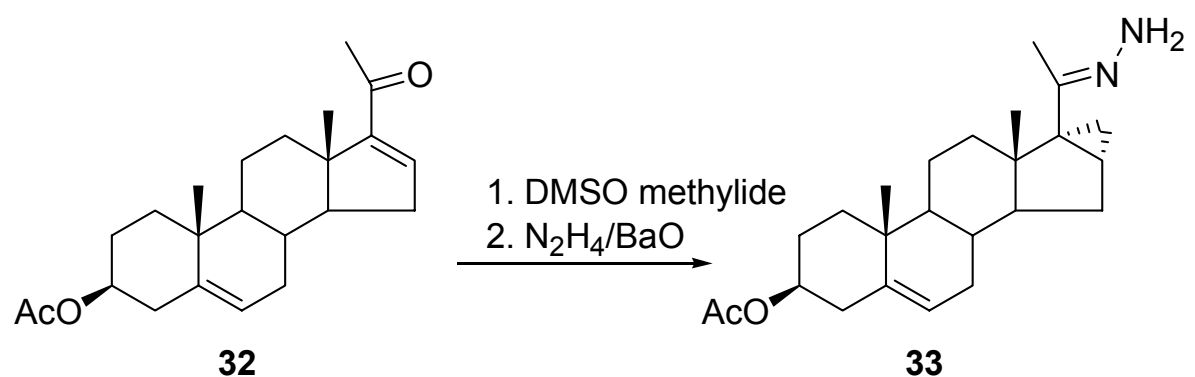

32

33

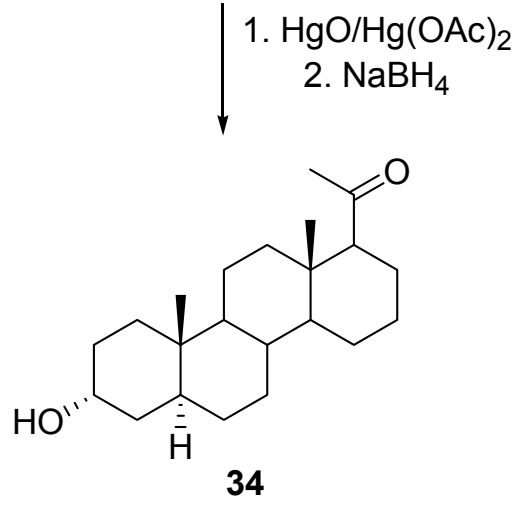

\section{Scheme 7}

\subsection{Fragmentation - cyclization strategies}

To obtain D-homoandrostenes or D-homoestranes, the introduction of one additional carbon atom into the molecules of the natural steroids is necessary. This can be achieved by the formylation of 17-ketosteroids at C-16. ${ }^{33} 16$-Formyl-17-ketosteroids (35) can be transformed into 
D-secosteroids (36), by including a Grob fragmentation as the key step (Scheme 8). ${ }^{34,35}$ These fragmentation products (39) bear two valuable functional groups, a formyl and an allyl group, which allow a wide range of further transformations.

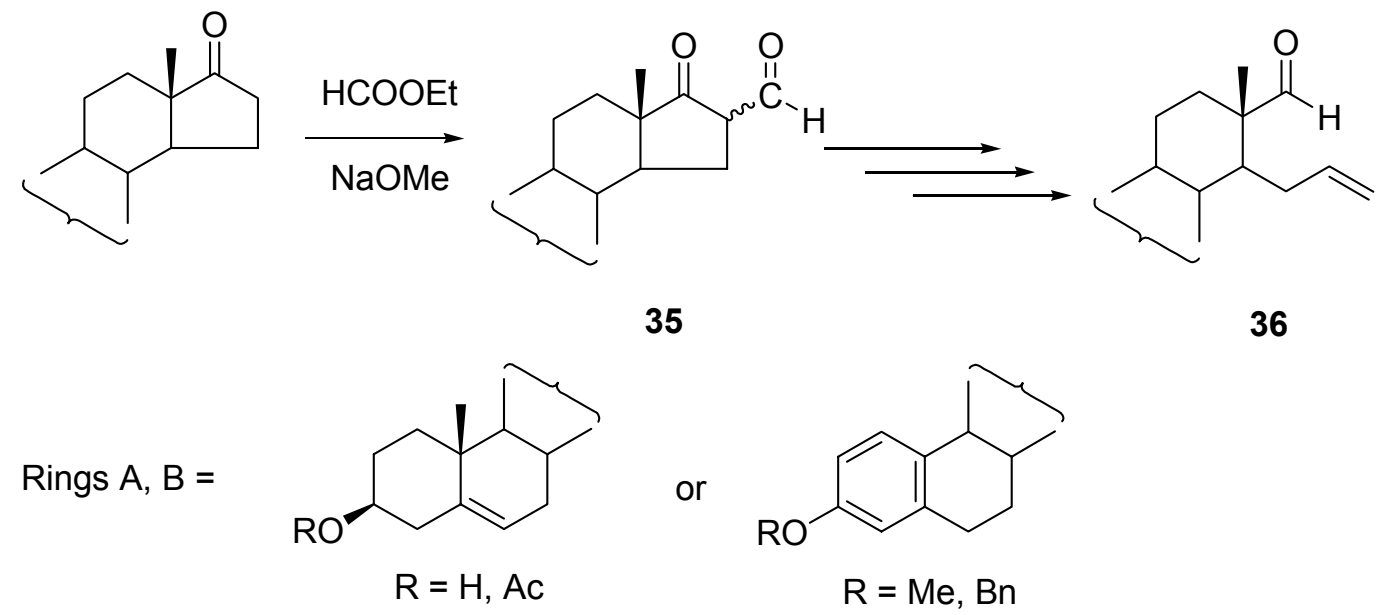

\section{Scheme 8}

An effective, simple epimerization of C-13 has been elaborated for the synthesis of 17-keto$13 \alpha-5$-androstenes ${ }^{36}$ and -estranes. ${ }^{37}$ The unnatural $13 \alpha$ derivatives, with $\mathrm{C} / \mathrm{D}$ cis ring annelation, are of stereochemical and biological interest. The 13 $\alpha$-estrone, 3-methyl (37) and 3benzyl ethers (38) have been converted into their epimers $(39,40)$ and D-seco derivatives (41, 42) in the above-mentioned way (Scheme 9). ${ }^{38,39}$
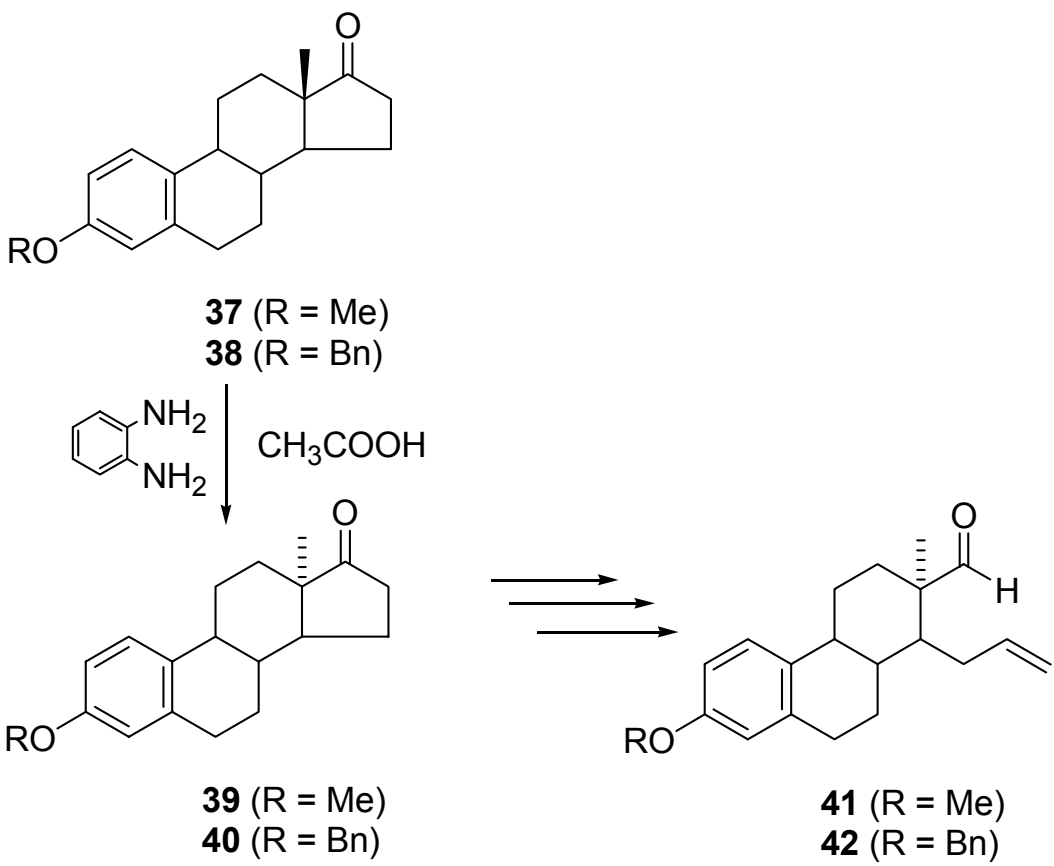

Scheme 9 
The 3-methyl- or 3-benzyl ethers of the D-secoestrone derivative 36 were converted in an intramolecular Prins reaction into halogen-containing D-homosteroids 43 in the presence of Lewis acids. ${ }^{40}$ Also, $\mathrm{F}, \mathrm{Cl}, \mathrm{Br}$ and I have been introduced into the $16 \beta$ position, through the use of $\mathrm{BF}_{3} \cdot \mathrm{OEt}_{2}, \mathrm{SnCl}_{4}, \mathrm{ZnBr}_{2}$ or $\mathrm{BF}_{3} \cdot \mathrm{OEt}_{2} / \mathrm{NaI}$, respectively (Scheme 10).

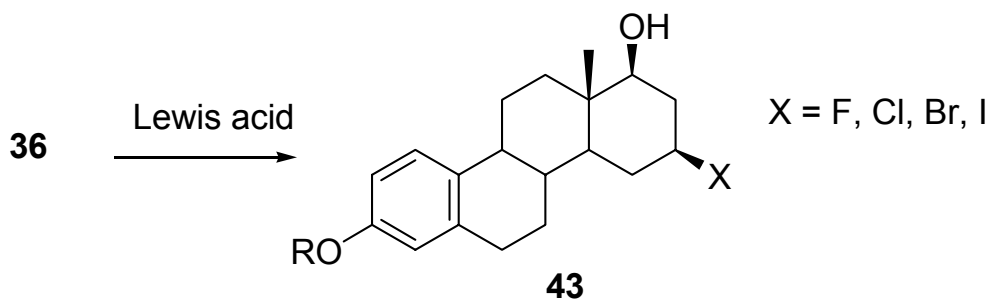

\section{Scheme 10}

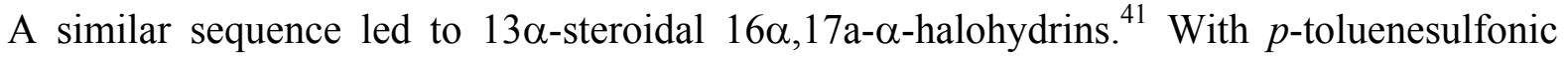

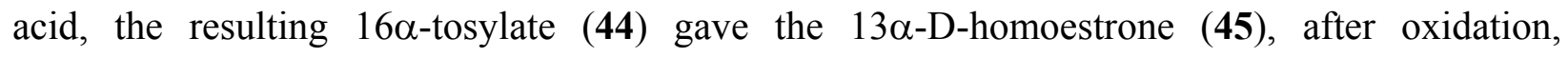
elimination, and hydrogenation (Scheme 11). 3-Hydroxy- and 3-methoxy-D-homoestrones in both the normal- and the $13 \alpha$ series have been tested in in vitro radioligand-binding assays. The $13 \alpha$-D-homoestrone derivatives are estrogen receptor-selective molecules. ${ }^{8}$

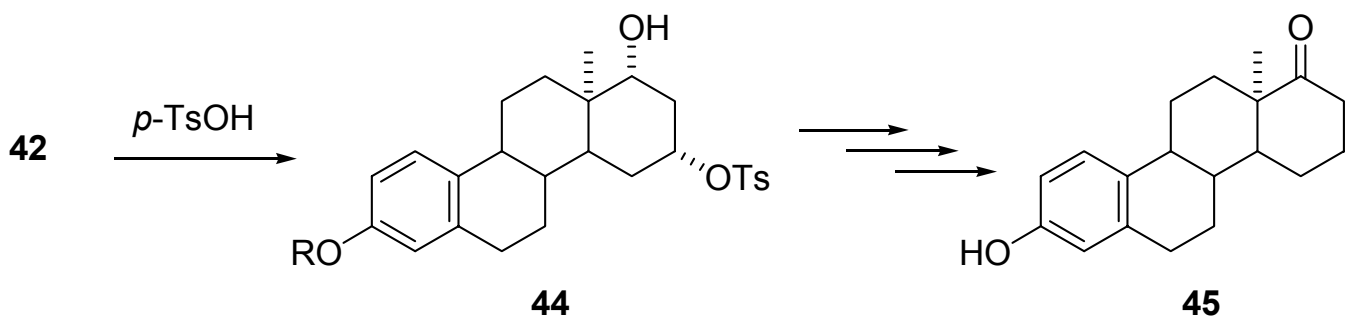

\section{Scheme 11}

Intramolecular Lewis-acid-catalyzed cyclizations of the steroid aryliminium salts $\mathbf{4 6}$ obtained from the secoestrone aldehyde $\mathbf{3 6}$ yielded either the tetrahydroquinoline derivatives of estrone 3methyl ether 47 or the $N$-arylamino-D-homosteroids 48 , depending on the nature of the substituent on the aniline moiety. For electron-withdrawing groups, such as $\mathrm{NO}_{2}$, formation of the D-homosteroid is favored (Scheme 12). ${ }^{42-44}$ 
<smiles>[R]c1ccc(/[N+]([Y19])=C\C[C@]2(C)CCC3c4ccc(OC)cc4CCC3C2CC=C)cc1</smiles>

$\mathrm{R}=\mathrm{H}, \mathrm{CH}_{3}, \mathrm{OMe}, \mathrm{Br}, \mathrm{NO}_{2}$<smiles>[R]c1ccc(N[C@@H]2CC([X])CC3C4CCc5cc(OC)ccc5C4CC[C@@]32C)cc1</smiles><smiles>[R]c1ccc2c(c1)C[C@H]1CC3c4ccc(OC)cc4CCC3[C@@H]1[C@@H]2C</smiles>

\section{Scheme 12}

A similar tendency could be observed in the $13 \alpha$-estrone series. Earlier investigations revealed that the conformations of rings $\mathrm{C}$ and $\mathrm{D}$ are strongly influenced by the substitution pattern on ring D. ${ }^{37}$ An X-ray crystallographic investigation showed the chair conformations of both rings $\mathrm{C}$ and $\mathrm{D}$ of a $16 \alpha$-fluoro-17a $\alpha$-arylamino-D-homoestrone derivative. ${ }^{45}$ The cyclization of iminium salts of a D-secopregnene aldehyde led to a $16 \beta$-arylamino-17 $\alpha$ aminomethyl-17 $\beta$-fluoro-D-homosteroid as a side-product. ${ }^{46}$<smiles>COc1ccc2c(c1)CCC1C2CC[C@]2(C)C(=O)/C(=N\O)CC12</smiles>

49
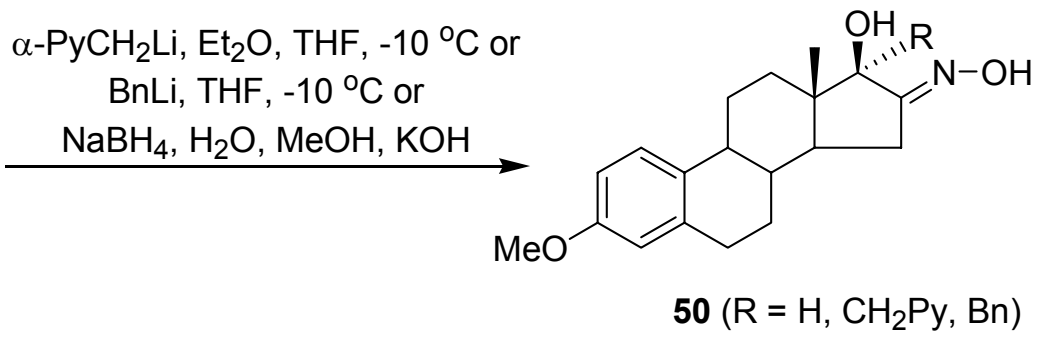<smiles>[R]C1=C(N)CC2C3CCc4cc(OC)ccc4C3CC[C@]2(C)C1=O</smiles>

$51 \mathrm{R}=\mathrm{Py}, \mathrm{Ph}$

\section{Scheme 13}


In a novel one-pot fragmentation-cyclization, $17 \beta$-hydroxy-17 $\alpha$-substituted 16-oximino derivatives in the androstane and estrane (50) series have been converted into a new type of Dhomosteroid derivatives (51; Scheme 13). ${ }^{47}$ The inhibitory effects of D-homo compounds of this type in the androstane series toward aromatase, $3 \beta$ - and 17 $\beta$-hydroxysteroid dehydrogenase, and $17 \alpha$-hydroxylase/C17, 20 lyase (P450c17) have been investigated. ${ }^{48}$

\subsection{Total synthetic approaches}

The classical Torgov method made possible the industrial-scale total synthesis of estrones. ${ }^{49}$ This reaction sequence can also be used to obtain D-homoestrones. ${ }^{50} \mathrm{~A}$ short, flexible, efficient method has been developed by Sarabèr and de Groot for the synthesis of 17-substituted steroid skeletons and D-homosteroid skeletons through the use of a $\mathrm{ZnBr}_{2}$-catalyzed coupling of a silyl enol ether-containing ring D precursor (53) with a Torgov-type reagent (52), followed by acidcatalyzed cyclization of the adducts (54), to furnish steroid and D-homosteroid skeletons (55; Scheme 14). ${ }^{51,52}$

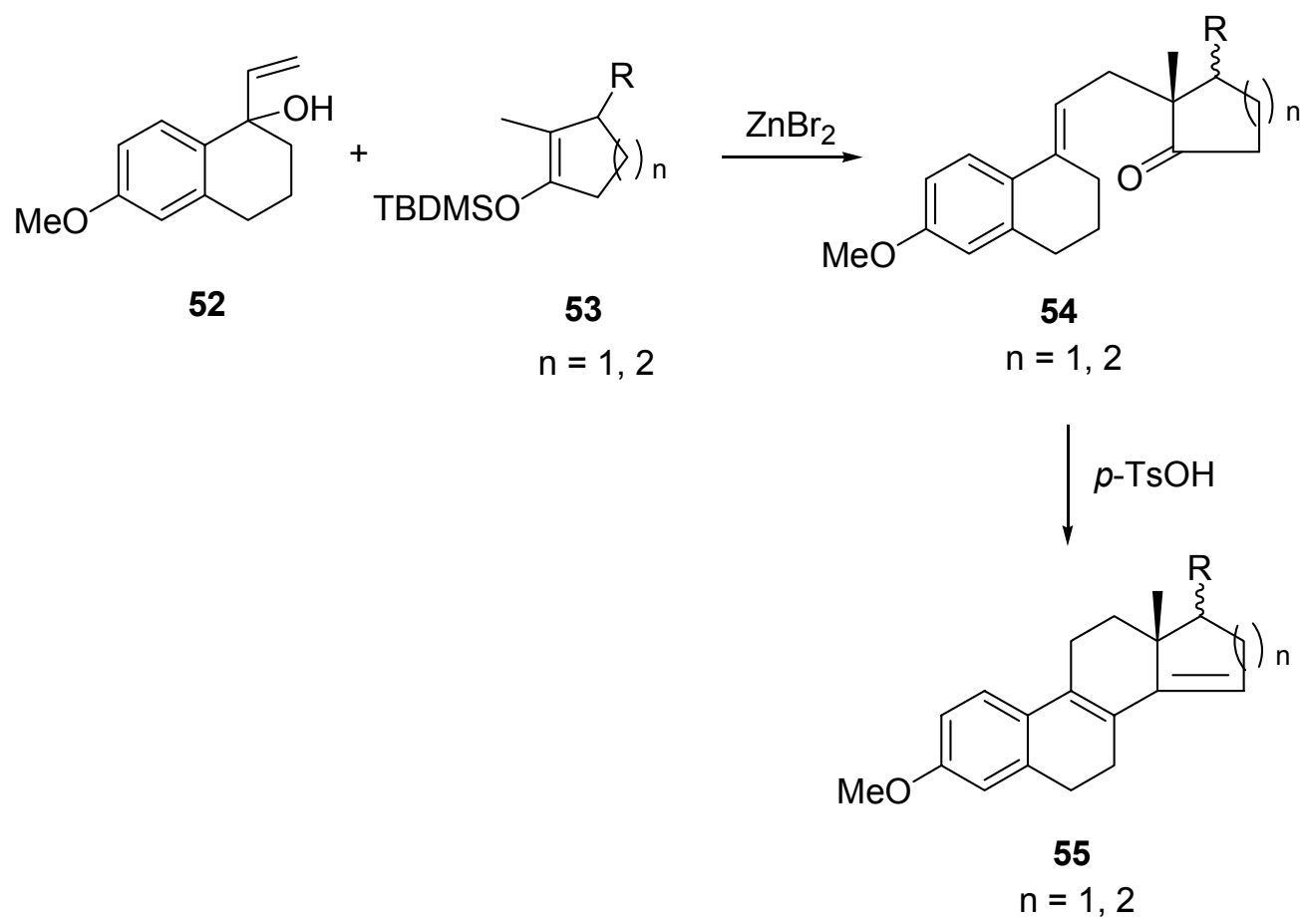

\section{Scheme 14}

In another approach by the de Groot group, an efficient procedure has been developed for the synthesis of C,D-cis-coupled steroid and D-homosteroid skeletons. A Mukaiyama reaction with transfer of the silyl group of the starting silyl enol ether $\mathbf{5 6}$ to the enol of the adduct, followed by the addition of vinyl magnesium bromide to the unprotected carbonyl group, leads to adducts 58, which have been cyclized with $\mathrm{ZnBr}_{2}$ to 59. The synthesis of functionalized steroid skeletons in 
overall yields of about $50 \%$ can be achieved in four steps in this way (Scheme 15). ${ }^{52,53}$ On the basis of Mukaiyama chemistry, a further efficient procedure has been developed to obtain C,Dcis annelated D-homosteroids. ${ }^{54}$<smiles>C=CC1(O)c2ccc(OC)cc2CCC1C1CCCC1COC(C)=O</smiles>
56

57

58

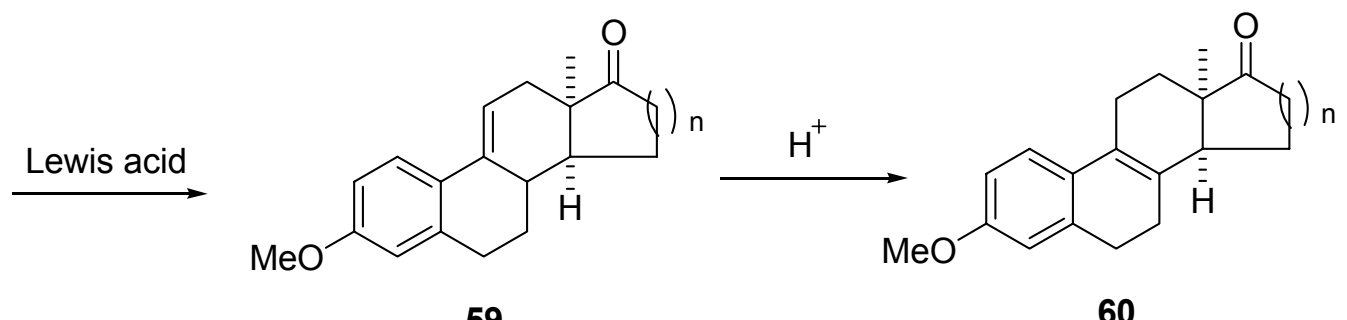

\section{Scheme 15}

The reaction of the cyclic $\beta$-cyanoketone 62 with 6-(3-methoxyphenyl)hex-1-en-3-one (61) gave the decalone cyanohydrin 63 , which could be cyclized to D-homosteroids $(64,65)$ under acidic conditions (Scheme 16). ${ }^{55}$<smiles>C=CC(=O)CCCc1cccc(OC)c1</smiles>

61

62<smiles>C=C(C)[C@@H]1C=C2C3=C(CCc4cc(OC)ccc43)[C@@]2(C)CC[C@H](C(=O)O)[C@@H]1C#N</smiles>

65

Scheme 16 
De Clerq et al. reported on the synthesis of a D-homo-10 $\alpha$-adrenosterone derivative (68), based on an intramolecular furan-diene Diels-Alder approach (Scheme 17). ${ }^{56}$

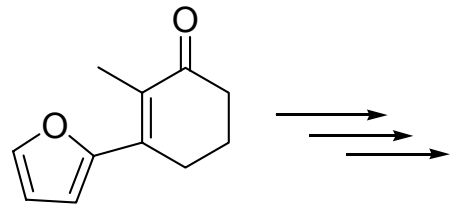

66<smiles>CC1(C)C(=O)CCC[C@H]2C1CCC1=CC(=O)CC[C@@]12C</smiles>

68<smiles>[R2]C1([R2])CCC[C@H](c2ccco2)[C@@]1(C)CC(=O)C=C=[R]</smiles>

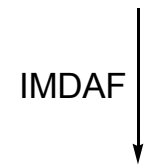<smiles>[R2]C1C2C=CC3(O2)C1C(=O)C[C@]1(C)[C@@H]3CCCC1([R2])[R]</smiles>

69

\section{Scheme 17}

The D-homosteroid $\mathbf{7 4}$ has been synthesized by Tietze and Petersen, by two successive Heck reactions, starting from enantiopure $\mathbf{7 1}$ and a bromoarene $\mathbf{7 0}$ containing a (Z)-bromovinyl group.

The first intermolecular Pd-catalyzed reaction led in a highly regio- and diastereoselective way to $\mathbf{7 3}$, which afforded $\mathbf{7 4}$ with an unnatural B/C cis-junction in a second intramolecular Heck reaction (Scheme 18). ${ }^{57}$

New, biomimetic, intramolecular methodology for the preparation of racemic Dhomosteroids has been described by Zoretic et al. ${ }^{58}$ The polyene 77 has been cyclized to the tetracycle 78 in a radical process. After removal of the ethoxycarbonyl functional group on C-4 and conversion of the angular cyano group on $\mathrm{C}-8$ into $\beta-\mathrm{H}, 4$-methyl-D-homoandrostanolone 79 was obtained (Scheme 19). 

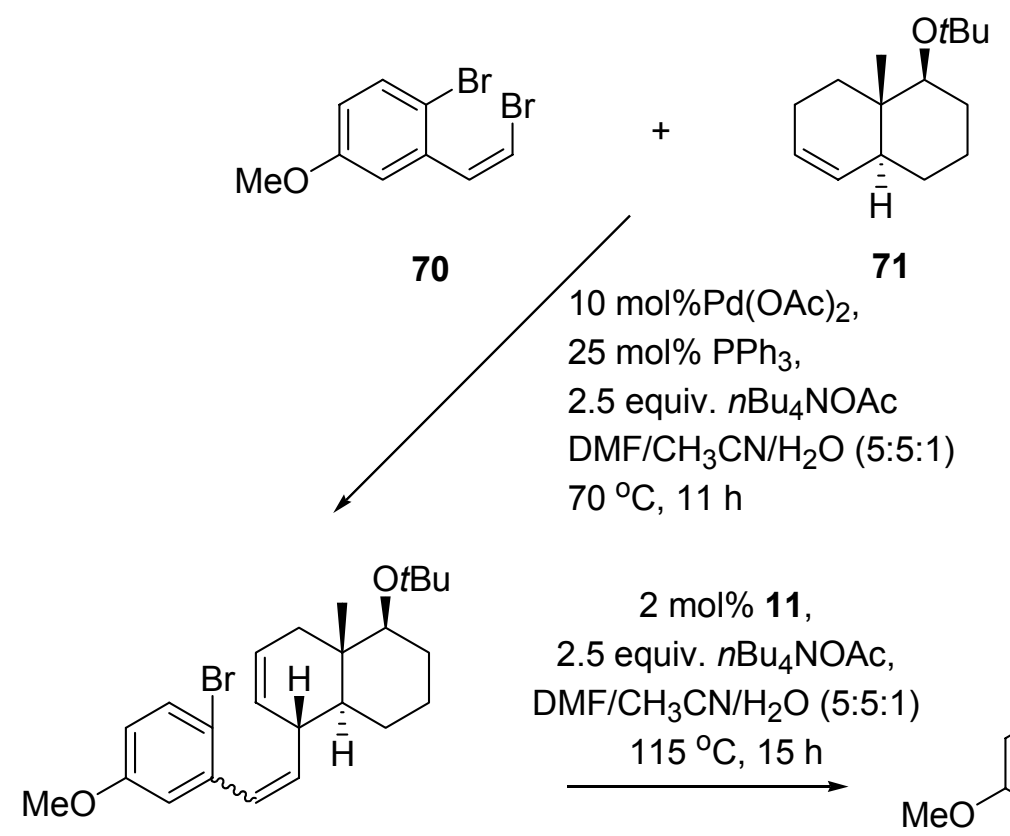

$52 \%, E(72): Z(73)=1: 4.2$

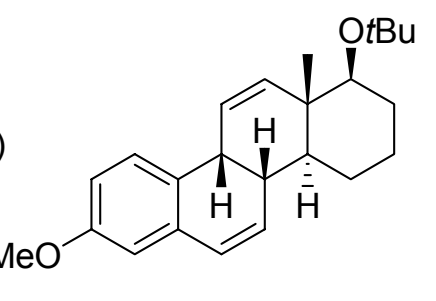

74

\section{Scheme 18}

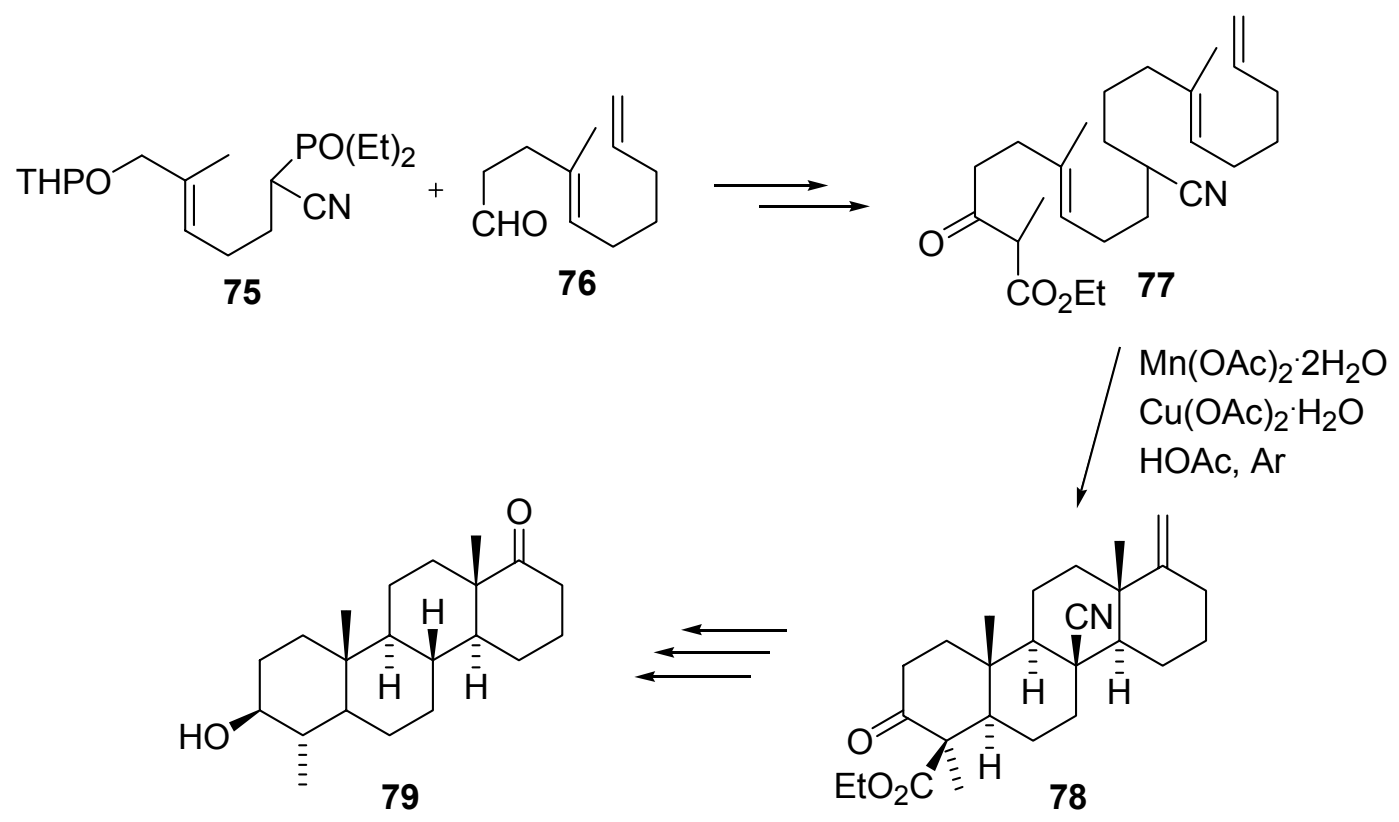

Scheme 19 


\subsection{Miscellaneous transformations and investigations}

A review has been published on the synthesis of 8 -azasteroids, including D-homo derivatives. ${ }^{59}$ Transformations of unsaturated derivatives of equilenin (80) and D-homoequilenin (81) have been performed (Figure 7). ${ }^{60}$

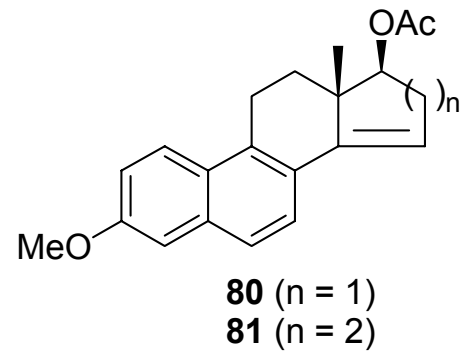

\section{Figure 7}

The properties and reactions of B-nor-8-iso analogs of D-homoestrone have been investigated. ${ }^{61}$ An NMR study has been performed on the stereo-structure and intramolecular dynamics of D-homoandrostenes and a B-nor-8-iso-D-homoestrone derivative. ${ }^{62}$ The crystal structures of two steroid 19,B-dinor-8,10-iso analogs ${ }^{63}$ and of two 6-oxa-D-homo-8-isoestra derivatives $^{64}$ have been published. An investigation has been made on the phosphorescence of enaminocarbonyl-8-azasteroids (including D-homo derivatives). ${ }^{65}$ The results of CI-MS investigations on 17-substituted estra- and 17a-substituted- D-homoestra- derivatives have been reported. ${ }^{66}$ Computational studies have shown that derivatives of tetrahydrochrisene (82) can be successfully docked into the second binding site of $\operatorname{ER} \alpha$ and $\operatorname{ER} \beta$ (Figure 8). ${ }^{67}$

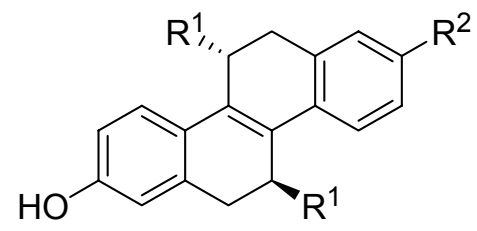

82

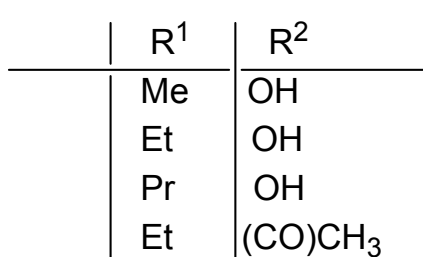

Et $\quad(\mathrm{CO}) \mathrm{CH}_{3}$

\section{Figure 8}

The metabolism of desogestrel has been studied in vivo after the administration of single oral doses to rats and dogs. In dogs, 17a-keto-D-homosteroids have been found among the metabolites of the progestogen. ${ }^{68}$

\section{Conclusions}

The pharmacological potential of natural D-homosteroids, which occur widely in various plants and marine organisms, is a driving force for the isolation of new derivatives and their structureelucidation. The considerable amount of recent partial and total synthetic work, directed to the 
preparation of D-homosteroids is a clear indication that this research will continue to comprise an important field of steroid chemistry in the future.

\section{Acknowledgements}

I am grateful to Prof. L.-F. Tietze for a long-time successful scientific cooperation, which included my Alexander von Humboldt fellowship in his Institute at Göttingen, and the student and researcher exchange between Göttingen and Szeged within the framework of the HungarianGerman Intergovernmental S\&T Program. This cooperation has led to numerous results, among them many on the synthesis of D-homosteroids. My thanks are due to the Hungarian Scientific Research Fund (OTKA grant T049366) for financial support and to D. Ondré for help with the preparation of the manuscript.

\section{References}

1. Hanson, J. R. Nat. Prod. Rep. 2006, 23, 886 (this is the most recent review; see also the earlier reviews by Hanson in the same journal).

2. Stéphan, E. Org. Prep. Proced. Int. 2006, 38, 217.

3. Mehta, G.; Singh, V. Chem. Soc. Rev. 2002, 31, 324.

4. Tietze, L. F.; Bell, H. P.; Chandrasekhar, S. Angew. Chem. Int. Ed. 2003, 42, 3996.

5. Salunke, D. B.; Hazra, B. G.; Pore, V. S. Curr. Med. Chem. 2006, 13, 813.

6. Tamminen, J.; Kolehmainen, E. Molecules 2001, 6, 21.

7. Duax, W. L.; Smith, G. D.; Swenson, D. C.; Strong, P. D.; Weeks, C. M.; Ananchenko, S. N.; Egorova, V. V. J. Steroid Biochem. 1981, 14, 1.

8. Wölfling, J.; Mernyák, E.; Frank, É.; Falkay, G.; Márki, Á.; Minorics, R.; Schneider, Gy. Steroids 2003, 68, 277.

9. Zakharova, N. A.; Sholina, S. I.; Kruglyakova, K. E.; Karpukhin, O. N.; Ananchenko, S. N.; Limanov, V. E.; Torgov, I. V.; Émanuél, N. M. Russ. Chem. Bull. 1966, 15, 429.

10. Teruya, T.; Nakagawa, S.; Koyama, T.; Suenaga, K.; Kita, M.; Uemura, D. Tetrahedron Lett. 2003, 44, 5171.

11. Teruya, T.; Nakagawa, S.; Koyama, T.; Arimoto, H.; Kita, M.; Uemura, D. Tetrahedron 2004, 60, 6989.

12. Lee, K. R.; Kozukue, N.; Han, J. S.; Park, J. H.; Chang, E. Y.; Baek, E. J.; Chang, J. S.; Friedman, M. J. Agric. Food Chem. 2004, 52, 2832.

13. Glendinning, J. I. Science 1993, 259, 582.

14. Atta-ur-Rahman; Ali, R. A.; Ashraf, M.; Choudhary, M. I.; Sener, B.; Turkoz, S. Phytochemistry 1996, 43, 907.

15. Shakirov, R. Chem. Nat. Compd. 1997, 33, 479. 
16. Shakirova, U. T.; Shakirov, R. Chem. Nat. Compd. 2001, 37, 474.

17. Akhtar, M. N.; Atta-ur-Rahman; Choudhary, M. I.; Sener, B.; Erdogan, I.; Tsuda, Y. Phytochemistry 2003, 63, 115.

18. Jiang, Y.; Li, P.; Li, H.-J.; Yu, H. Steroids 2006, 71, 843.

19. Endo, H.; Warashina, T.; Noro, T.; Castro, V. H.; Mora, G. A.; Poveda, L. J.; Sanchez, P. E. Chem. Pharm. Bull. 1997, 45, 1536.

20. Atta-ur-Rahman; Choudhary, M. I. Nat. Prod. Rep. 1999, 16, 619.

21. For the first application of the Tiffeneau rearrangement to obtain D-homosteroids, see: Goldberg, M. N.; Monnier, R., Helv. Chim. Acta 1940, 23, 376.

22. Pellicciari, R.; Natalini, B.; Fringuelli, R. Steroids 1987, 49, 433.

23. Girdhar, N. K.; Ishar, M. P. S.; Kumar, R.; Singh, R.; Singh, G. Tetrahedron 2001, 57, 7199.

24. Cabeza, M.; Heuze, I.; Bratoeff, E.; Ramírez, E.; Martínez, R. Chem. Pharm. Bull. 2001, 49, 525.

25. Soriano-García, M.; Hernández-Ortega, S.; Bratoeff, E.; Valencia, N.; Ramírez, E.; Flores, G. J. Chem. Crystallogr. 1998, 28, 487.

26. Cabeza, M.; Heuze, I.; Bratoeff, E.; Ramírez, E.; Martínez, R.; Murillo, E. Proc. West. Pharmacol. Soc. 2001, 44, 99.

27. Bratoeff, E.; Herrera, H.; Ramírez, E.; Solorzano, K.; Murillo, E.; Quiroz, A.; Cabeza, M. Chem. Pharm. Bull. 2000, 48, 1249.

28. Nicoletti, D.; Ghini, A. A.; Baggio, R. F.; Garland, M. T.; Burton, G. J. Chem. Soc., Perkin Trans. 1 2001, 1511.

29. Fu, X.; Chan, T.-M.; Tann, C.-H.; Thiruvengadam, T. K. Steroids 2002, 67, 549.

30. Litvinovskaya, R. P.; Drach, S. V.; Khripach, V. A. Russ. J. Org. Chem. 2000, 36, 599.

31. Di Chenna, P. H.; Ghini, A. A.; Burton, G. Molecules 2000, 5, 447.

32. Di Chenna, P. H.; Ferrara, A.; Ghini, A. A.; Burton, G. J. Chem. Soc., Perkin Trans. 1 2001, 227.

33. Schneider, Gy.; Vincze, I.; Hackler, L.; Dombi, Gy. Synthesis 1983, 665.

34. Schneider, Gy.; Vincze, I.; Hackler, L.; Szabó, J. A.; Dombi, Gy. Acta Chim. Acad. Sci. Hung. 1982, 110, 429.

35. Schneider, Gy.; Bottka, S.; Hackler, L.; Wölfling, J.; Sohár, P. Liebigs Ann. Chem. 1989, 263.

36. Yaremenko, F. G.; Khvat, A. V. Mendeleev Commun. 1994, 187.

37. Schönecker, B.; Lange, C.; Kötteritzsch, M.; Günther, W.; Weston, J.; Anders, E.; Görls, H. J. Org. Chem. 2000, 65, 5487.

38. Tietze, L. F.; Schneider, Gy.; Wölfling, J.; Fecher, A.; Nöbel, T.; Petersen, S.; Schuberth, I.; Wulff, C. Chem. Eur. J. 2000, 6, 3755.

39. Wölfling, J.; Mernyák, E.; Forgó, P.; Schneider, Gy. Steroids 2003, 68, 451.

40. Frank, É.; Mernyák, E.; Wölfling, J.; Schneider, Gy. Synlett 2002, 419.

41. Wölfling, J.; Frank, É.; Mernyák, E.; Bunkóczi, G.; Cuesta Seijo, J. A.; Schneider, Gy. Tetrahedron 2002, 58, 6851 . 
42. Wölfling, J.; Frank, É.; Schneider, Gy.; Bes, M. T.; Tietze, L. F. Synlett 1998, 1205.

43. Frank, É. Magy. Kém. Folyóirat 2002, 108, 39.

44. Noltemeyer, N.; Tietze, L. F.; Wölfling, J.; Frank, É.; Schneider, Gy. Acta Cryst. 1996, C52, 2258.

45. Mernyák, E.; Schneider, Gy.; Herbst-Irmer, R.; Kubas, M.; Wölfling, J. Steroids 2006, 71, 558.

46. Magyar, A.; Wölfling, J.; Kubas, M.; Cuesta Seijo, J. A.; Sevvana, M.; Herbst-Irmer, R.; Forgó, P.; Schneider, Gy. Steroids 2004, 69, 301.

47. Penov-Gaši, K.; Miljković, D.; Medić-Mijačević, L.; Đurendić, E.; Petrović, J.; Pejanović, V.; Stanković, S.; Lazar, D. Tetrahedron Lett. 1998, 39, 9759.

48. Penov Gaši, K. M.; Miljković, D. A.; Medić Mijačević, L. D.; Djurendić, E. A.; Stojanović, S. Z.; Sakać, M. N.; Djurendic, M. D.; Stanković, S. M.; Lazar, D.; Andrić, S.; Kovačević, R. Steroids 2003, 68, 667.

49. Nazarov, I. N.; Torgov, I. V.; Verkholetova, G. N. Dokl. Akad. Nauk. SSSR 1957, 112, 1067.

50. Ananchenko, S. N.; Limanov, V. Y.; Leonov, V. N.; Rzheznikov, V. N.; Torgov, I. V. Tetrahedron 1962, 18, 1355.

51. Sarabèr, F. C. E.; de Groot, A. Tetrahedron Lett. 2004, 45, 9431.

52. Sarabèr, F. C. E.; Dratch, S.; Baranovsky, A.; Charnikhova, T; Pogrebnoi, S.; Jansen, B. J. M.; de Groot, A. Polish J. Chem. 2006, 80, 535.

53. Dratch, S.; Charnikhova, T.; Sarabèr, F. C. E.; Jansen, B. J. M.; de Groot, A. Tetrahedron 2003, 59, 4287.

54. Sarabèr, F. C. E.; Baranovsky, A.; Jansen, B. J. M.; Posthumus, M. A.; de Groot, A. Tetrahedron 2006, 62, 1726.

55. Sobolev, A.; Vos, M.; Zuilhof, H. T.; Sarabèr, F. C. E.; Jansen, B. J. M.; de Groot, A. Arkivoc 2005, (xiv), 29.

56. Claeys, S.; Van Haver, D.; De Clercq, P. J.; Milanesio, M.; Viterbo, D. Eur. J. Org. Chem. 2002, 1051.

57. Tietze, L. F.; Petersen, S. Eur. J. Org. Chem. 2000, 1827.

58. Zoretic, P. A.; Chen, Z.; Zhang, Y. Tetrahedron Lett. 1996, 37, 7909.

59. Surya Prakash Rao, H; Senthilkumar, S. P. Curr. Org. Chem. 2004, 8, 1521.

60. Urusova, E. A.; Gluzdikov, I. A.; Selivanov, S. I.; Starova, G. L.; Nikolaev, S. V.; Shavva, A. G. Russ. J. Org. Chem. 2004, 40, 506.

61. Shavva, A. G.; Selivanov, S. I.; Starova, G. L.; Boronoeva, T. R.; Ishchenko, I. V.; Gluzdikov, I. A.; Sharetskii, A. N.; Isaeva, V. G.; Surinov, B. P. Russ. J. Bioorg. Chem. 2002, 28, 215.

62. Selivanov, S. I.; Shavva, A. G. Russ. J. Bioorg. Chem. 2002, 28, 194.

63. Egorov, M. S.; Starova, G. L.; Shavva, A. G. Acta Cryst. 2002, C58, o170.

64. Starova, G. L.; Selivanov, S. S.; Egorov, M. S.; Selivanov, S. I.; Shavva, A. G. Cryst. Rep. 2004, 49, 437. 
65. Bagnich, S. A.; Khropik, N. N.; Mikhalchuk, A. L.; Rubinov, D. B. J. Fluoresc. 2003, 13, 495.

66. Zaikin, V. G.; Borisov, R. S. Eur. J. Mass. Spectrom. 2003, 9, 459.

67. van Hoorn, W. P. J. Med. Chem. 2002, 45, 584.

68. Verhoeven, C. H. J.; Krebbers, S. F. M.; Wagenaars, G. N.; Vos, R. M. E. Drug Metab. Disp. 1998, 26, 927. 